\title{
Transfer kulturowy w klasycznym tańcu indyjskim odissi w Indiach
}

Dym kadzideł, zapach świeżych kwiatów, ciepła poświata $z$ lampionu oświetlającego drewnianą figurę bożka o dużych oczach, dźwięki dzwoneczków wybijane rytmicznie stopami i dłonie rzucające jakieś zaklęcia albo opowiadające jakąś historię. Twarz przepełniona emocjami i ciało niczym ożywiona figura z rzeźb świątynnych, zmysłowe, piękne i harmonijne, a zarazem przybierające formę różnych postaci bóstw, potworów, kochanków, drzew, wód i zwierząt. Czy to tylko taniec, czy rówież teatr? A może to jakiś rytuał lub modlitwa? Impresje te mogłyby stanowić przykład pierwszych wrażeń widza oglądającego taniec odissi na deskach teatru, gdzieś w małym miasteczku europejskim. Taniec mocno osadzony w rdzennej tradycji stanu Orissa w Indiach, chociaż mobilny i wędrujący po całym świecie. Taniec odissi nigdy nie był jednolitą i zamkniętą formą. Wiele różnych wpływów kształtowało jego historię, był podatny na zmiany, ulegał przekształceniom, stanowił projekt w ciągłym procesie twórczym.

Posługując się koncepcją transferu kulturowego, a przede wszystkim opierając się na jego czterech aspektach omówionych przez Dominika Picka, w tym artykule podejmuję się analizy zmian zachodzących w klasycznym tańcu indyjskim odissi pod wpływem zachodnich koncepcji, idei i praktyk. Będę analizować metodologię nauczania oraz praktykę współczesnych tancerzy odissi z Instytutu Tańca Nrityagram, a także prace tancerki Sharmili Mukherjee w Bangalorze. W tekście omawiam również kwestię koniunktury, rozpatrując podłoże socjokulturowe w Indiach: liberalizację gospodarki, która pozwoliła na otwarcie się na rynek światowy, wpływ globalizacji oraz mobilność, czyli migracje tancerek. Biorę pod uwagę „migrującego tancerza”, który poznaje nowe praktyki ćwiczeń kondycyjnych, pracy nad ciałem i techniki tańca, a także inspiruje się motywami europejskich tańców oraz swobodnie przenosi i wciela je do swoich praktyk „w domu”. Opisuję i analizuję wybrane idee, koncepcje i praktyki zachodnie jako przedmiot transferu. Równocześnie badam proces przyswajania przedmiotu transferu, jego kontekst oraz wpływ inspiracji z Zachodu na stosowane praktyki w tańcu odissi, a także przemiany z tym związane. 
Odissi to jedna z ośmiu form klasycznego tańca indyjskiego, który wywodzi się ze wschodniego stanu Orissa w Indiach. Dziś taniec ten praktykowany jest na całym świecie niezależnie od narodowości, płci, religii czy koloru skóry. Na jego kształtowanie się wpłynęło jednak wiele różnych praktyk osadzonych w samym regionie Orissy, jak i w całych Indiach, wpływały na niego rzeźby świątynne, antyczne traktaty o tańcu i muzyce, manuskrypty na liściach palmowych, rytualny taniec mahari (tancerek świątynnych w Orissie, będących ekwiwalentem devadasi, służebnic bożych z południa Indii) w świątyniach; odgrywanie żeńskiej formy miłosnego oddania Krisznie poprzez akrobatyczny taniec Gotipua (młodych chłopców przybierających w tańcu formę, strój i makijaż kobiecy) z ich elementem rozrywkowym; religijny i erotyczny wiersz miłosny Gïtagovinda, teatr Orissy, lokalna kultura folkowa i plemienna, wiele różnych wierzeń religijnych, tradycji regionalnych, a także ruch i działania z życia codziennego. Jest to jedna z najnowszych form indyjskiego tańca klasycznego, biorąc pod uwagę jej rekonstrukcję i przynależność do grupy ośmiu klasycznych tańców Indii, wedle klasyfikacji, która powstała w latach sześćdziesiątych XX wieku. Mimo tej typologii odissi uważane jest za najstarszą antyczną formę tańca w Indiach, czego dowodzą archeologiczne odkrycia w Orissie sięgające II wieku p.n.e. ${ }^{1}$. Dynamika płciowa w tradycyjnym podziale na rolę męskiego nauczyciela oraz kobiet tancerek, a także świątynny taniec wykonywany przez kobiety, pozostawiły w tańcu charakterystyczny kobiecy i zmysłowy akcent. Wizualne atrybuty tańca odissi, jak obfitość srebrnej biżuterii, białej korony nawiązującej do architektury świątynnej oraz uszyty na miarę kostium z „saree” pochodzących z Orissy, są ściśle powiązane z regionalnymi i rdzennymi formami rękodzieł i tradycji (Zdj. 1).

Cztery główne postawy ciała, wokół których elaboruje się kroki i choreografię, to: sama - prosta, äbhanga - załamana w jednym miejscu, tribhangi - załamana $\mathrm{w}$ trzech miejscach oraz chouka - kwadratowa postawa. Tradycyjny repertuar składa się z pięciu tańców. Inaugurujący taniec mangalacharan jest utworem inwokacyjnym, poprzez który składane są modły wybranemu bóstwu; najczęściej jest to Jagannath (forma Visznu czczona w Orissie). Potem następują dwa tańce w czystej formie: batu i pallavi, w których można zauważyć korelacje figur świątynnych z rytmem artykułowanym przez śpiewaka oraz wybijanym na instrumencie perkusyjnym zwanym pakhawadź. Tańce te uważane są za czystą formę tańca lub nritta, piękne, zmysłowe niczym tańczące rzeźby, ale bez narracji. Tańce narracyjne lub nrittya są nazywane abhinaya, co można przetłumaczyć

1. Kapila Vatsyayan, Orissi, w: Indian Classical Dance, Publications Division, Ministry of Information and Broadcasting, Government of India, New Delhi, 1974; Dhirendranath Patnaik, odissi Dance, Orissa Sangeet Natak Akademi, Bhubaneswar, 1971. 


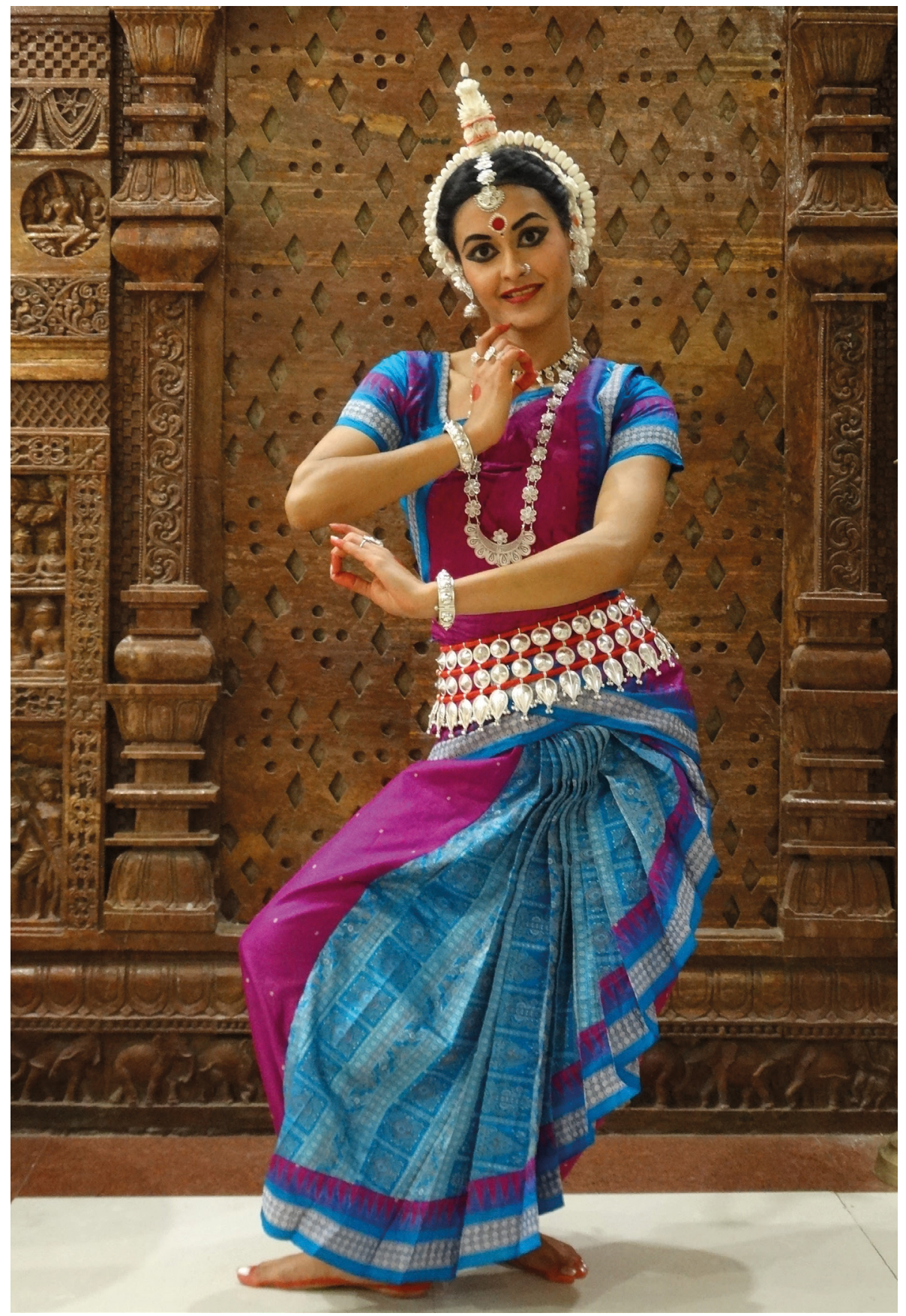

Zdj. 1. Tancerka odissi w tradycyjnym kostiumie (Zdjęcie: Dagmara Sen) 
z Sanskrytu jako gra aktorska. Termin składa się z dwóch członów: prefiks „abhi” oznacza w kierunku, a rdzeń „ni” - prowadzić2. Słowo można zatem przetłumaczyć jako prowadzenie w kierunku rasy, emocji i estetycznego doświadczenia, smaku czy najwyższej rozkoszy. Widz doświadcza rasy przez osobę performera. Tancerka, poprzez gesty dłoni, ekspresję twarzy, ruch ciała („āngikaabhinaya”), muzykę i słowa piosenki („vācikaabhinaya”), kostium, charakteryzację („āhāryaabhinaya”) oraz bezwarunkowe psychofizyczne ekspresje („sāttvikaabhinaya”), przedstawia historię i wyraża emocje. Najczęściej używane pieśni do abhinaya pochodzą z Pieśni o Pastuszku (Gitagowinda), wiersza lirycznego dwunastowiecznego poety Jayadevy, a także z wierszy takich pisarzy z Orissy, jak Banamali Das, Salabega czy Gopal Krushna Patnaik. Finałowy taniec mokśa, w którym tancerka w pełni oddaje się Bogu, funkcjonuje jako symbol wyzwolenia duszy zgodnie z wierzeniami religijnymi i filozofią hinduską. Tenże pełny repertuar zgodnie z tradycją powinien być tańczony przez solistów. Dziś bardzo popularne stały się choreografie z uczestnictwem nawet kilkunastu tańczących. Są to rozbudowane formy abhinaya, przybierające format spektaklu teatralno-tanecznego. $Z$ tradycyjnego punktu widzenia równie trudne do zaakceptowania wydawałby się recital taneczny odbywający się bez muzyków i śpiewaków, którzy powinni na żywo grać dla tancerzy. Mimo to obecnie, zwłaszcza poza granicami Indii, najczęściej odtwarzana jest muzyka nagrana wcześniej w studio. Takich zmian można dostrzec więcej i wiele z nich ma związek z transferem kulturowym, powstającym przez „ciągłe przywłaszczanie elementów kultury obcej przejmowanych jako część kompleksowego i przeobrażającego procesu redukcji i reinterpretacji, którego rezultat pozwala nam na podkreślenie różnic"3. W dalszej części artykułu koncentruję się na zmianach zachodzących w tańcu odissi w wyniku transferu kulturowego, omawiam kwestię aktorów transferu kulturowego i jej koniunktury. Następnie analizuję sferę psychofizycznego przygotowania „ciałaumysłu” do tańca oraz sytuację adaptacji dzieła z obcego gatunku tanecznego.

2. Manomohan Ghosh, Natyashastra: A Treaties on Ancient Indian Dramaturgy and Histrionics Ascribed to Bharata Muni, Chowkhamba Sanskrit Series Office, Varanasi, 2002, s. 150-151.

3. Matthias Middell, European History and Cultural Transfer, „Diogenes”, 2000, 189, 48, s. 27. <http://www.blackwellpublishing.com/content/BPL_Images/Journal_Samples/DIOG03921921 48 1 029/026.PDF> [Przeł. S.S.S.P.].

4. „Ciałoumysł” to termin tłumaczony z angielskiego „bodymind”, odnoszący się do człowie$\mathrm{ka} /$ tancerza, postrzeganego jako istotę, u którego umysł i ciało są na równi istotne i funkcjonują w jednym zintegrowanym systemie. Jest to podejście odbiegające od dualistycznego spojrzenia ciała-umysłu czy ciała i umysłu. 


\section{Migrujący tancerze i wzajemne interferencje między kulturami prowadzące do rozbudzenia świadomości psychosomatycznej w tańcu odissi}

Dominik Pick określa bardzo ważną funkcję aktorów transferu kulturowego, za pośrednictwem których tworzone i przenoszone są media, idee czy dobra kulturowe $^{5}$. Ta istotna rola wynika $z$ ich „tymczasowego lub dłuższego zanurzenia się w innej kulturze"6. W przypadku tańca odissi można znaleźć przykłady migrujących tancerzy, którzy poznają nowe praktyki ćwiczeń kondycyjnych, pracy nad ciałem i techniki tańca oraz swobodnie przenoszą i wcielają je do swoich praktyk, stanowiąc jeden z podstawowych motorów funkcjonowania transferu kulturowego. Pierwszą tancerką odissi mającą bezpośrednią relację z teatrem zachodnim była Sanjukta Panigrahi, która opisuje swoje doświadczenia z udziału w seminariach Międzynarodowej Szkoły Antropologii Teatru (ISTA), gdzie aktywnie uczestniczyła i współpracowała z Eugenio Barbą oraz z innymi artystami w latach 1980-1996. Przyznała, że nauczanie poza Indiami to wyzwanie, ponieważ „oni [uczestnicy - S.S.S.P.] nie znają Indii czy ich tradycji” " Nowe miejsca, ludzie, kontekst zmuszają do przyswojenia nowych sposobów odniesienia, pojawia się wiele warstw korelujących ze sobą, które wpływają na sposób przekazywania wiedzy. Mamy tu do czynienia z przedmiotem transferu rozumianym przez Picka jako „przemieszanie się ludzi, koncepcji, idei, systemów symbolicznych, przedmiotów materialnych systemów prawnych itp., a więc wszystkiego, co w szerokim

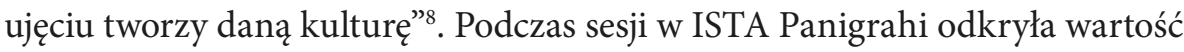
świadomości ciała i ruchu w odissi, twierdząc: „Zaczęłam myśleć, co moje ciało dokładnie robi w trakcie tańca. Odkryłam, że mogłam czuć każdą część mojego ciała. Mogłam zdefiniować rolę, jaką pełni każda część mojego ciała w trakcie tworzenia się tańca. Stopniowo nauczyłam się techniki ISTA i potrafiłam odczuwać moje kończyny, moje ciało... i to też pomagało w nauczaniu w Indiach"9. Stanowi to ostatni element definicji transferu kulturowego według Picka, czyli procesu przyswajania nowych treści kulturowych. W nowym doświadczeniu

5. Dominik Pick, Czym jest transfer kultury? Transfer kultury a metoda porównawcza. Możliwości zastosowania transferts culturels na gruncie polskim, w: Monolog, dialog, transfer. Relacje kultury polskiej i niemieckiej w XIX i XX wieku, red. Mirosława Zielińska, Marek Zybura, Wrocław, Centrum Willy'ego Brandta, Wrocław 2013, s. 258.

6. Middell, European History and Cultural Transfer..., s. 26. [Przeł. S.S.S.P.].

7. Ron Jenkins, Ian Watson, odissi and ISTA Dance: An Interview with Sanjukta Panigrahi, Negotiating Cultures: Eugenio Barba and the Intercultural Debate, red. Ian Watson, Manchester University Press, Manchester, 2002, s. 73. [Przeł. S.S.S.P.].

8. Pick, Czym jest transfer kultury?..., s. 255.

9. Jenkins, Watson, odissi and ISTA Dance..., s. 69. [Przeł. S.S.S.P.]. 
z ISTA Panigrahi rozpoznała zmysł kinestetyczny, który poszukuje „głębszego zrozumienia ruchu będącego w samym sobie sposobem poznania, medium, które nosi znaczenie poprzez bezpośrednie odczuwanie, w sposób somatyczny"10. Z powodu wczesnej śmierci w wieku 53 lat Panigrahi nie miała możliwości rozwinięcia swojej nowej metody nauczania. Mimo to przykład pierwszego kontaktu tancerki z artystami w ISTA ukazuje, w jaki sposób migrujący tancerz jest w stanie przyswoić obcą kulturę i włączyć ją do swoich praktyk. Panigrahi twierdziła, że współpraca z ISTA obudziła w niej świadomość ciałaumysłu, który był „uciszony” w jej ówczesnym treningu i miał znaczący wpływ na kształtowanie jej własnego sposobu nauczania. Wśród współczesnych tancerzy odissi znajdziemy osoby, które - podobnie do artystki - doskonale zdają sobie sprawę z istotności zdrowia i sprawności „ciałaumysłu” dla tancerzy oraz stworzyły na podstawie badań i praktyk własne metodologie nauczania tańca. Jednak nim przytoczę tu jeden $\mathrm{z}$ takich instytutów tańca, to wpierw odpowiem na pytanie, skąd wzięło się to nagłe zainteresowanie ciałem jako elementem równie istotnym, co umysł czy dusza. Odpowiedź najlepiej znaleźć, wyjaśniając kwestię koniunktury jako jednego z elementów transferu kulturowego.

Według Picka „koniunktura ma miejsce, gdy nowe treści są z jakiegoś powodu interesujące dla przedstawicieli kultury przyjmującej"11. Postrzeganie ciała jako czegoś drugorzędnego w społeczeństwie indyjskim zrodziło się „pod wpływem wrażliwości budowanej ideałami zachodnimi” ${ }^{12}$ oraz w wyniku zamieszania powstałego ze zderzenia tradycji Indii $\mathrm{z}$ wpływami zachodnimi ${ }^{13} \mathrm{w}$ okresie kolonizacji brytyjskiej i po uzyskaniu niepodległości przez Indie. W efekcie joga wraz z ajurwedą i aromaterapią „były uważane za »staromodne« w latach siedemdziesiątych i osiemdziesiątych XX wieku i musiały najpierw zostać na nowo ukształtowane i wprowadzone w rynek europejski i amerykański”, by później w latach dziewięćdziesiątych zdobyć rynek indyjski ${ }^{14}$. Sytuacja ta doskonale obrazuje funkcje tranferu kulturowego nie jako pojedyńczego zjawiska kontaku i wymiany kulturowej, a jako wyniku „długotrwałych procesów rozwojowych

10. Deidre Sklar, Reprise: On Dance Ethnography, „Dance Research Journal”, 2000, 32 (1), s. 70. [Przeł. S.S.S.P.]

11. Pick, Czym jest transfer kultury?..., s. 256.

12. Archana Verma, Eroticism in Indian Classical Dance: odissi, w: Performance and Culture: Narrative, Image and Enactment in India, red. Archana Verma, Cambridge Scholar Publishing, Newcastle, 2011, s. 53. [Przeł. S.S.S.P.].

13. Rekha Menon, The Politics of the Sensuous and the Sacred Body in India, „Paragrana”, 2009, 18(1), s. 284-305.

14. Christiane Brosius, India's Middle Class: New Forms of Urban Leisure, Consumption and Prosperity, Routledge, New Delhi, 2010, s. 311. 
wzajemnych kulturowych interferencji”' ${ }^{15}$. Ponadto liberalizacja polityki, ekonomii i otwarcie się Indii na rynek światowy w latach dziewięćdziesiątych doprowadziły do pojawienia się nowej klasy średniej z jej kosmopolityczną tożsamością ${ }^{16}$. Zmiany w obrębie polityki i ekonomii miały bezpośredni wpływ na socjokulturową stronę funkcjonowania narodu. Od 1996 roku mężczyźni i kobiety stali się bardzo świadomi najnowszych trendów fizycznej sprawności i zdrowia, a „nowe kody i przepisy na »dobre życie« odwoływały się do specyficznych form fizycznego i psychicznego zdrowia i piękna"17. To już nie krągłe i zmysłowe, lecz szczupłe i perfekcyjnie wyrzeźbione ciało stało się nowym wskaźnikiem bogactwa oraz dobrobytu ${ }^{18}$. Shoma Munshi wskazuje na przybycie tego ideału do Indii w latach dziewięćdziesiątych XX wieku w efekcie naśladowania zachodnich wzorców perfekcyjnego ciała ${ }^{19}$, a Sangita Shreshtova twierdzi, że to filmy Bollywood są głównym środkiem jego popularyzacji ${ }^{20}$. Konkursy piękności odegrały równie istotną rolę w ustanawianiu tej nowej tożsamości współczesnej Hinduski, która plącze się pomiędzy dyskursem globalnym i lokalnym ${ }^{21}$.

Wysoka świadomość zdrowia i sprawności fizycznej ciała współczesnych tancerzy zachodnich również jest ważnym elementem wpływu. Dziś centra fitness i zajęcia ze współczesnych tańców zachodnich można znaleźć w każdym indyjskim mieście, a wizualnej promocji tej kultury jest pełno w mediach, przede wszystkich na mediach społecznościowych, jak Facebook. Warsztaty i seminaria dotyczące zdrowia, sprawności fizycznej tancerzy, w których udział biorą fizjoterapeuci, nauczyciele jogi, fitnessu, praktycy ruchów somatycznych, lekarze i tancerze z Indii oraz z zagranicy, organizowane są w ramach festiwali tańca w całych Indiach. W świetle tej socjokulturowej zmiany tancerki odissi również stały się bardziej świadome potrzeby wypełnienia luk w swojej metodologii nauczania. Dla niektórych tancerzy fitness stał się ważnym elementem ich życia codziennego. Z praktycznym i świadomym podejściem zarówno do estetyki, jak i zdrowia,

15. Joanna Jabłkowska, Transfer kulturowy czy po prostu kontakty?, w: TEATR - LITERATURA - MEDIA. O polsko-niemieckich oddziaływaniach w sferze kultury po 1989 roku, red. Małgorzata Leyko, Artur Pełka, Primum Verbum, Łódź 2013, s. 34.

16. Brosius, India's Middle Class..., Leela Fernandes, India's New Middle Class: Democratic Politics in an Era of Economic Reform, University of Minnesota Press, Minneapolis, 2006.

17. Brosius, India's Middle Class..., s. 307, 309.

18. Brosius, India's Middle Class..., s. 308.

19. Shoma Munshi, Images of the 'Modern Woman' in Asia: Global Media, Local Meanings, Curzon Press, Surrey, 2001, s. 87.

20. Sangita Shreshtova, Is It All about Hips? Around the World with Bollywood Dance, SAGE Publications, New Delhi \& London, 2011.

21. Munshi, Images of the 'Modern Woman'..., Brosius, India's Middle Class..., Radhika Parameswaran, Global Media Events in India: Contests over Beauty, Gender and Nation, „Journalism \& Communication Monographs", 2001, 3(52), s. 53-105. 
a także pod wpływem manii fitnessu, tancerze uważają „pięknie” wyrzeźbione i silne ciało za sedno wspierania wewnętrznej duszy tańca. Prezentuje to nowy ideał atletycznego ciała i tancerzy w pełni świadomych swojego „ciałaumysłu”.

\section{Glokalne formy psychosomatyczne \\ w metodologii nauczania i w praktyce tańca odissi}

Współczesne formy sportu zostały skategoryzowane jako „glokalne”, ponieważ „są one zagorzale globalne w kwestii organizacji i struktury, a jednocześnie nieugięcie lokalne w sposobie, w jakim są uprawiane i doświadczane"22. Znajdując się pomiędzy dyskursem globalnym a lokalnym oraz współczesnym a tradycyjnym, tancerki odissi również stale negocjują te polarności. W rozwijaniu swoich strategii treningów kondycyjnych przyjmują one podejście eklektyczne i glokalne.

Trening kondycyjny w Nrityagram jest ważnym elementem, powiązanym i jednocześnie wyodrębnionym od głównych sesji tanecznych. W swoich codziennych praktykach i w treningu w Nritygramie, tancerze - poza hatha jogą i kalarippayattu - sięgają też po pilates, ćwiczenia z baletu oraz po współczesny taniec Ranjabati Sircar. Ćwiczenia są ponadto prowadzone z odpowiednim słownictwem i podejściem na bazie metod Feldenkraisa. Jak twierdzi Bijayini Satpathy, która jest dyrektorką edukacji tanecznej w Nrityagram, te wszystkie techniki mają sprawić, by studenci czuli się wygodnie i naturalnie w głównych postawach tańca. Używają metod Feldenkraisa w celu usprawnienia tańca oraz poprawy funkcjonowania „ciałaumysłu”. Nrityagram konsekwentnie czerpie z metody Feldenkraisa w celu osiągnięcia efektów, o których mówi Glenna Batson. Według Batson ćwiczenia oparte na praktykach somatycznych są zaprojektowane tak, by „pobudzały zmysły oraz uświadamiały, jakie są dysfunkcjonalne postury i zwyczaje ruchowe, [...] a także organizowały w pełni wspartą i zintegrowaną całość ciała do ruchu"23. Pilates jest praktykowany w celu wzmocnienia mięśni tułowia, a ćwiczenia z baletu mają wzmacniać nogi i ułatwiać ruch nogi w en dehors (wykręcenie). Ranjabati Sircar, która jest uważana za kluczową performerkę w rozwoju współczesnego tańca indyjskiego, stworzyła metodologię, która „otwarcie zawiera indyjskie i euro-amerykańskie systemy treningu tanecznego"24, oferując międzydyscyplinarny trening kondycyjny, promowany przez Nrityagram.

22. D. L. Andrews, C. Batts, I M.L. Silk, Sport, Glocalization and the New Indian Middle Class, „International Journal of Cultural Studies”, 2013, 17(3), s. 261. [Przeł. S.S.S.P.].

23. Glenna Batson, Dancing Fully, Safely, and Expressively: The Role of the Body Therapies in Dance Training, „Journal of Physical Education, Recreation \& Dance”, 190, 61(9), s. 28. [Przeł. S.S.S.P.].

24. Prarthana Purkayastha, Indian Modern Dance, Feminism and Translationalism, Palgrave Macmillan, Basingstoke, 2014, s.142. [Przeł. S.S.S.P.]. 
Linda Ashley uważa, że „dla tancerza i choreografa aktywnie wykorzystywana świadomość dotycząca bezpiecznej praktyki może służyć zarówno do wyjaśniania, jak należy wykonać dany ruch, jak i dlaczego pewne frazy ruchowe sprawiają trudnośćn" ${ }^{25}$. Wiedza o bezpiecznym treningu i anatomii ciała może wydawać się oczywista dla tancerza, jednak tradycyjny program nauczania klasycznego tańca indyjskiego nie obejmował anatomii ani fizjologii. W wywiadzie zarówno Uttara Asha Coorlawala, jak i Kapila Vatsyayan podkreślają kwestię nieobecności świadomości ciała w studiach o tańcu indyjskim ${ }^{26}$. Tancerki, które wykazują się tą świadomością, samodzielnie odkryły ją i douczyły się jej w późniejszym stadium swojej kariery. Satpathy twierdzi, że jej rolą jest stworzenie metodologii nauczania odissi, które to nauczanie jest możliwie najbardziej metodyczne, naukowe, zorganizowane i wolne od urazów ${ }^{27}$. Jej podejście doskonale oddaje percepcję człowieka, zdefiniowaną przez Thomasa Hanny jako "ciało samo-świadome, samo-czujące, samo-ruszające i samo-odpowiedzialne"28. Swoje zainteresowania w tej sferze Satpathy rozwinęła po zaobserwowaniu niszczącego efektu tradycyjnego treningu oraz po jej przyjeździe do Nrityagram, gdzie odkryła niekończące się możliwości badań i rozwoju.

Surupa Sen, dyrektorka artystyczna Nrityagram, główna choregrafka i tancerka, w trakcie Międzynarodowego Amerykańskiego Festiwalu Tańca w 2000 roku miała okazję dowiedzieć się między innymi o kluczowej roli odpowiedniego podłoża tanecznego dla zdrowia i bezpieczeństwa tańczących, co spowodowało, że po powrocie sama ufundowała drewnianą specjalistyczną podłogę w głównej sali tanecznej w Nrityagram. Podczas rozmów z uczestnikami letnich warsztatów ${ }^{29}$ opowiadała, jak stała się świadoma urazów, które mogą być wywołane przez niewłaściwe podłoże używane w tańcu w Indiach (np. podłoga cementowa) czy też brak odpowiedniego przygotowania i rozgrzania ciała przed rozpoczęciem tańca. Tancerze w Nrityagram roztaczają świadomą i pełną opiekę nad ciałem - korzystają z fizjoterapii oraz spożywają żywność organiczną, lekkostrawną, ale o dużej zawartości białka. W planach mają też zbudowanie Centrum „Whole Body Centre", które zawierać ma dwa studia taneczne z drewnianym podłożem do tańca, salę gimnastyczną, osobne sale do jogi i masażu, a także saunę i jacuzzi ${ }^{30}$.

25. Linda Ashley, The Essential Guide to Dance, Hodder Education, Oxon, 2008, s. 1. [Przeł. S.S.S.P.].

26. Uttara Asha Coorlawala, Kapila Vatsyayan, Kapila Vatsyayan: Formative Influences, „Dance Research Journal”, 2000, 32(1), s. 104.

27. Wywiad z Bijayini Satpathy przeprowadzony przez autorkę26.07.2014. Bangalore, Indie [Przeł. S.S.S.P.].

28. Thomas Hanna, Somatics: Reawakening the Mind's Control of Movement, Flexibility, and Health, Da Capo Press, Cambridge, 1988, s. 21. [przeł. S.S.S.P.].

29. Letnie warsztaty w Nrityagram (2014), w których uczestniczyła autorka. Temat: Nrityagram Summer Workshop 2014, 1.07-28.07.2014, Bangalore, Indie.

30. Nrityagram, The Future <www.nrityagram.org > (12.08.2014). 
W praktyce tańca istotę wizualizacji i obrazowania zauważyli zarówno tancerze, jak i praktycy form somatycznych ${ }^{31}$. Eric Franklin w książce o użyciu obrazowania w dynamicznym pozycjonowaniu tańca twierdzi, że „zarówno obrazy, jak i słowa w naszych umysłach wpływają na to, co czujemy w ciele, a to z kolei informuje nasze myśli i obrazy mentalne"32. Głównym powodem używania obrazów i wizualizacji w tańcu jest to, że:

Mentalne obrazy poprawiają pozycjonowanie i koordynację ruchową przez zmianę dróg odruchowych, podświadomych w systemie nerwowym, dając możliwość tancerzom i nauczycielom na wyjście poza niechciane fizyczne nawyki, które kolidują z pełnią ekspresji wolności cielesnej w tańcu ${ }^{33}$.

Filozof Mark Johnson, badający możliwość ugruntowania poznania w doświadczeniach cielesnych, twierdzi, iż metafory, które tworzymy i których używamy w poszczególnych językach, są istotą tworzenia-znaczenia (meaning-making) ${ }^{34}$. Naśladując trening tańca zachodniego, metafory i obrazy użyte w nauce głównych postaw w odissi umożliwiają kompletną psychosomatyczną realizacją abstrakcyjnego ruchu. Satpathy używa metafory jako wskazówki dla studentów w ich rozumowaniu:

Ja jedynie nadaję słowa doświadczeniu, uczuciu, by mieli jakiś punkt zaczepienia. To zawsze jakieś skojarzenie, obraz lub wizualizacja czegoś stają się bardziej pomocne niż powiedzenie „podnieś bardziej ramię, rozciągnij je mocniej”35.

Ten sposób użycia metafory poprzez słowa koreluje z użyciem wyobraźni w celu usprawnienia wykonania danego ruchu przez Feldenkraisa, który uważał, że „systematyczne poprawianie obrazu jest szybszym i efektywniejszym podejściem niż poprawianie z osobna każdego ruchu i błędu w trybach zachowania. [...]"36.

Czerpiąc $\mathrm{z}$ techniki oddychania w jodze, obrazu balonu oraz metafory effort (wysiłek) i release (wydłużenie ruchu, rozluźnienie), zaadaptowanego z zachodniego tańca współczesnego, Satpathy tłumaczy korelację oddechu z ruchem w odissi:

31. Lulu E. Sweigard, Human Movement Potential: Its Ideokinetic Facilitation, Harper and Row, New York, 1974; Mabel Elsworth Todd, The Thinking Body: A Study of the Balancing Forces of Dynamic Man, Dance Horizons, New York, 1937.

32. Eric Franklin, Dynamic Alignment through Imagery, Human Kinetics, USA, 1996, s. x. [przeł. S.S.S.P.].

33. Harlene Goldschmidt, Dancing with Your Head On: Mental Imagery Techniques for Dancers, "Journal of Dance Education”, 2002, 2(1), s. 19. [przeł. S.S.S.P.].

34. Mark Johnson, The Meaning of the Body: Aesthetics of Human Understanding, The University of Chicago Press, Chicago, 2007, s. 280 [przeł. S.S.S.P.].

35. Wywiad z Bijayini Satpathy.

36. Moshe Feldenkrais, Awareness through Movement: Health Exercises for Personal Growth, Penguin, Ontario, 1984, s. 23. [przeł. S.S.S.P.]. 
To jest tak, że to jest release, a tamto jest effort, używamy bardzo dużo tych słów. Wraz $\mathrm{z}$ wydechem ma miejsce release, a effort jest jak robimy wdech, i naturalnie dochodzi do podniesienia, ponieważ release zawsze idzie w dół. To jest jak z balonem, nadmuchany sięga dalej, jest wyżej, a opada i zmniejsza się, gdy się kurczy, jak wdech i wydech. Te same zasady stosuje się do każdego ruchu ${ }^{37}$.

W tym opisie Satpathy używa image schemata / embodied schemata (schematów wyobrażeniowych czy ucieleśnionych): góra - dół i do środka - na zewnątrz. Johnson twierdzi, że „ruch ciała ludzkiego, manipulacje obiektów i percepcyjne interakcje angażują powtarzające się wzorce", które nazywa image schemata $(\text { schematem wyobrażeniowym) })^{38}$. Praca filozofa koncentruje się na udowodnieniu ucieleśnionej natury naszego codziennego języka poprzez lingwistykę kognitywną. Jednak $\mathrm{z}$ uwagi na podstawę schematów wyobrażeniowych w doświadczeniu percepcyjnym schematy wyobrażeniowe stają się pomocnym narzędziem także w ucieleśnionym nauczaniu tańca. Jak wyjaśnia Johnson: „one nie tyle »obrazująu czy »reprezentują» obiekty i wydarzenia, ile same są wzorcami naszych doświadczeń tych obiektów i wydarzen" 39 . W trakcie zajęć Satpathy powiedziała: „rozluźnij uda jak siadasz do chouka” i byłam w stanie wejść w tę postawę ze spokojnym i jednocześnie uważnym „ciałoumysłem”. Wzięłam głęboki wdech, po czym, wydychając powietrze, zeszłam w dół do siadu w pozycji chouka z wizualizacją piłki delikatnie kładzionej na platerze (Schemat 1).

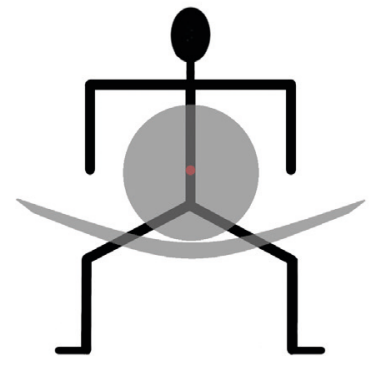

Schemat 1. Piłka na platerze: dynamiczne obrazowanie w siadzie do chouka.

37. Wywiad z Bijayini Satpathy.

38. Mark Johnson, The Body in the Mind: The Bodily Basis of Meaning, Imagination, and Reason, University of Chicago Press, Chicago 1987, s. xix. [Przel. S.S.S.P.].

39. Johnson, The Meaning of the Body..., s. 243. 
W tym samym czasie mogłam uwolnić napięcie w mięśniach uda poprzez wydech i utrzymać się w tej postawie przez dłuższy czas, niż gdy robiłam to poprzednio bez zastosowania obrazowania i bez świadomości ruchu czy anatomii.

Kolejny aspekt użycia metod zachodnich pojawia się w kontekście ciężaru i równowagi. Pojęcie ciężaru zostało włączone w zachodnią metodologię treningu przez Rudolfa Labana, który mówił o nim, że to „siła wywierana na ciele poprzez pole grawitacyjne [oraz, że] o ile odnosimy się do ruchu, to z pewnością może on wpływać na nasze relacje z przestrzenią i czasem". Laban stworzył też ćwiczenia do zrozumienia przez „ciałoumysł” tego, jak ciężar jest używany w ruchu ${ }^{40}$. Zgodnie z Podstawami Bartenieffa (Bartenieff Fundamentals) ${ }^{41}$ „odczuwanie ciężaru” jest świadectwem tego, że tancerz ma „świadomość proprioceptywną o tym, że każda kończyna i tułów są stale w relacji z grawitacją"42.

Zrozumienie odczuwania ciężaru wraz z equilibriocepcją (równowagą) stało się kluczowym elementem współczesnego treningu głównych postaw tańca odissi dla tancerek w Nrityagram. Znalazły one własny sposób na włączenie tego w swoją metodologię. Na przykład w nauce postawy chouka używają treningu ciężaru w połączeniu z techniką tańca improwizacji kontaktowej. Satpathy wyjaśnia, że ,jedna osoba kuca w pozycji chouka a druga osoba siada na nią i robią przysiady, więc fizycznie stajemy się bardzo nieskrępowani [niczym nieograniczeni i swobodni w ruchu - S.S.S.P.]”33. Te ćwiczenia budują wytrzymałość, a poprzez świadomość dotykową i equillibriocepcję pogłębiają rozumienie pozycji. Równowaga poprzez zmysłową świadomość jest dalej ćwiczona, kiedy uczniowie czują się wystarczająco komfortowo w pozycji chouka, by próbować robić tę pozycję na mniej wygodnych podłożach, jak na przykład na ruchomej platformie zwanej „Core Board” czy piłeczce zwanej „Swiss ball”. To angażuje ich do odkrywania wszystkich, nawet "najmniejszych mięśni, których nie jesteśmy w stanie sobie wyobrazić" ${ }^{\prime 4}$. W procesie treningu nauczyciele Nrityagram wykazują też świadomość „utrzymania równowagi pomiędzy użyciem optymalnego poziomu napięcia, gdy wykonywane jest zadanie, a użyciem technik relaksacji w celu obniżenia poziomu napięcia, kiedy pozwala na to moment odpoczynku”" ${ }^{\prime 35}$. Widać to zwłaszcza w uwadze poświęconej rozgrzewce, „cool down”46 i w ćwiczeniach używanych pomiędzy sekwencjami tanecznymi.

40. Jeane Newlove, John Dalby, Laban for All, Routledge, London, 2004, s. 119. [przeł. S.S.S.P.]

41. Podstawy Bartenieffa to system metod i ćwiczeń prawidłowego ruchu ciała opracowanego przez Irmgarda Bartenieffa.

42. Peggy Hackney, Making Connections: Total Body Integration through Bartenieff Fundamentals, Routledge, Oxon, 2002, s. 265 [przeł. S.S.S.P.].

43. Wywiad z Bijayini Satpathy.

44. Wywiad z Bijayini Satpathy.

45. Sally Fitt, Dance Kinesiology, Schirmer Books, New York, 1996, s. 305. [przeł. S.S.S.P.].

46. „Cool down” to wyciszenie organizmu, rozluźnienie mięśni po treningu. 
Przytoczone tu przykłady pokazują, jak szkoła Nrityagram zaadaptowała praktyki somatyczne, zachodnie style tańca i techniki fitnessu do swojego treningu. Z jednej strony wydawałoby się, że ta „glokalna” metodologia została celowo stworzona dla zachodniej publiczności oraz dostosowana do potrzeb zagranicznych studentów, którzy są doskonale zorientowani w kwestiach technik kondycji ciała i praktyk somatycznych. Okazuje się jednak, że metodologia treningu w Nrityagram nie tylko ma na celu przyciąganie zagranicznych studentów, lecz także jest adresowana do dojrzałych tancerzy odissi, którzy chcą podejść do tego tańca analitycznie, z pełną świadomością metodologii. Tu należy wspomnieć, że zasady treningu i działania szkoły Nrityagram wywodzą się od matki założycielki, Protima Bedi, i jej progresywnego światopoglądu, a także otwartego podejścia w kształtowaniu oblicza szkoły. Bedi promowała ideę treningu międzydyscyplinarnego, doceniając inne formy tańca i przyjmując elementy obce, które można wcielić we własną pracę. W jej autobiografii Timepass ${ }^{47}$ można przeczytać o tym, że joga, kalaripayattu i chhau były praktykowane od samego początku powstania tej wioski tanecznej w latach dziewięćdziesiątych XX wieku. Satpathy dodaje, że Bedi mówiła im: „[...] róbcie to, co czujecie [...], co instynktownie jest Wasze, a ja będę Was wspierac'”48. Tak też podążając za swoim instynktem i praktycznym myśleniem, tancerki włączyły do odissi techniki kondycyjne z obcych dziedzin. Satpathy tłumaczy też:

Jeśli zadam Ci robienie tradycyjnych ćwiczeń do odissi, przez miesiąc wzmocnisz tułów (core). Ale jest to bardzo niszczący sposób pracy. Jeśli w zamian możesz leżeć i robić pilates, to dlaczego nie ${ }^{49}$.

Mimo praktycznych zastosowań technik zachodnich, tradycjonaliści oskarżają Nritygaram o hybrydyzację odissi i wybieganie poza jej tradycyjne ramy. Zamiast krytykować wpływy zachodnich tańców współczesnych i metod fitnessu, można spojrzeć na to tak, jak proponuje Purkayastha:

[...] musimy uznać, że w świecie kolonialnym, jak i postkolonialnym międzykulturowe eksperymenty w tańcu były dość powszechne, gdzie choreografowie z każdej części globu poszukiwali odmiennych tematów, form, sposobów prezentacji w celu wzbogacenia swoich praktyk artystycznych ${ }^{50}$.

47. Protima Bedi, Pooja Bedi Ebrahim, Timepass: The Memoirs of Protima Bedi, Penguin Books, New Delhi, 2000.

48. Wywiad z Bijayini Satpathy.

49. Wywiad z Bijayini Satpathy.

50. Purkayastha, Indian Modern Dance..., s. 119. 
Nawiązując do inspiracji czerpanych przez międzykulturowe eksperymenty, należy zwrócić uwagę na to, że tancerki Nrityagram sięgnęły po metody i praktyki zachodnie, jak pilates, metoda Feldenkraisa czy współczesne formy tańca, które same w sobie mają charakter synkretyczny, a ich powstanie było w pewnym stopniu inspirowane wschodnimi praktykami i holistyczną filozofią podejścia do ciała. W tym zjawisku wyraźnie widać kluczowy aspekt transferu kulturowego - wzajemne i długotrwałe wpływy między kulturami, o których wspomina też Jabłkowska ${ }^{51}$. Interakcja $\mathrm{z}$ wieloma choreografami i tancerzami, którzy odwiedzili Nrityagram, a także podróże nauczycielek Nrityagram zmotywowały je do poszukiwania związków i podobieństw miedzy odissi a tymi obcymi formami. Sen i Satpathy zmodyfikowały te techniki tak, by służyły tańcu odissi. Satpathy podkreśla, że to ich własna praca, a nie zapożyczenie z obcych gatunków i technik. Ich doświadczenie jest znakomitą ilustracją jednego z etapów transferu kulturowego, o którym Pick pisze: „transferowane treści tracą obcy kulturze przyjmującej charakter i stają się jej integralną częścią (zostają uznane za swoje)"52.

\section{Hansika jako indyjskie wcielenie rosyjskiego baletu Jezioro Eabędæie}

Nie tylko na etapie przygotowania „ciałaumysłu” do tańca, ale w samej realizacji tańca można znaleźć inspiracje napływające spoza granic Indii. Balet, jako zachodnia forma tańca klasycznego, miał duży wpływ na powstanie kategorii indyjskich tańców klasycznych. Samo zapożyczenie terminu „,klasyczny”, jak wskazuje Royo, miało na celu indygenizację oraz nadanie nowo odtworzonemu tańcowi statusu narodowego i międzynarodowego w okresie po uzyskaniu niepodległości przez Indie ${ }^{53}$. Balet pełnił tu funkcję odpowiedniego wzorca, z którego można czerpać, by stworzyć ekwiwalent doniosłej i docenianej formy dla elit indyjskiego społeczeństwa. Rukmini Devi-Arundale, reformatorka tańca Bharatanatyam i współtwórczyni kategorii klasycznego tańca indyjskiego, osobiście pobierała naukę baletu od uczennicy Anny Pavlovej, Cleo Nordi ${ }^{54}$. Istotnym aktorem transferu kulturowego w tym kontekście oraz reformatorem tańców indyjskich jest także Uday Shankar, który początkowo był studentem malarstwa w Royal College of Art w Londynie, ale jego spotkanie z Anną Pavlovą w 1923 roku przerodziło się we współpracę nad baletem o tematyce hinduskiej jak na przykład Radha

51. Jabłkowska, Transfer kulturowy czy po prostu kontakty?, s. 49.

52. Pick, Czym jest transfer kultury?..., s. 257.

53. Alessandra Lopez y Royo, Classicism, Post-classicism and Ranjabati Sircar's Work: Re-defining the Terms of Indian Contemporary Dance Discourses, „South Asia Research”, 2003, 23(2), s. 156.

54. Royo, Classicism, Post-classicism ..., s. 157. 
i Kriszna. Kontynuował pracę z baletem w Europie, jak i w Ameryce Północnej, nabierając różnorodnych doświadczeń ze spotkań i pracy między innymi z Alice Boner, Michaiłem Czechowem, Kurtem Jossem czy Rudolfem Labanem. Po tej międzynarodowej karierze Shankar stał się pionierem współczesnego tańca indyjskiego, nad którym pracę kontynuował w szkole Almora, będącej wtedy pierwszą i jedyną taką instytucją w Indiach ${ }^{55}$. Jak opisuje Purkayastha, Shankar wprowadził element improwizacji, nawiązał relacje między gestami codziennego życia i tańcem, stworzył system tańca, który bierze pod uwagę ciało i jego różne komponenty. Podkreślał wagę odosobnionego ruchu każdej części ciała $i$ ich symbiotycznej relacji z przestrzenią oraz wzorami przestrzennymi, a także wyraźnie mieszał elementy dynamiki z południowej Azji z zasadami wczesnego tańca współczesnego i zachodniego teatru ${ }^{56}$. Po jego śmierci jego córka Mamata Shankar, aktorka i tancerka, kontynuuje nauczanie tańca według stylu Uday Shankar w Kalkucie. Jego taniec stał się inspiracją dla wielu młodych pokoleń tancerzy, wychowujących się w Kalkucie, którzy, jeśli nie w jego szkole tańca, to w innych miejscach uczyli się wypracowanego przez niego stylu.

Podobnie kontakt $\mathrm{z}$ baletem i tańcem Udaya Shankara miała tancerka tańca klasycznego odissi - Sharmila Mukherjee, gdy w wieku 12 lat mieszkała w Kalkucie. Jej pierwsze fascynacje baletem sięgają 7 roku życia, kiedy, jako uczennica szkoły Loreto House prowadzonej przez irlandzkie zakonnice, uczęszczała na zajęcia baletu prowadzone przez rosyjską nauczycielkę. Mukherjee wspomina też o książkach i albumach ze zdjęciami baletnic, takich jak Anny Pavlovej, które pobudzały jej zainteresowanie tą formą tańca ${ }^{57}$. Choć osobiście zdecydowała się na profesjonalną karierę z tańcem odissi, to jednak fascynacja z dzieciństwa skłoniła ją do sięgnięcia po ikonę sztuki baletowej - Jezioro Łabędzie Piotra Czajkowskiego. Adaptacja tego baletu jest przykładem transferu kulturowego. Zanalizuję proces jego przyswajania i wpływ, jaki adaptacja Mukherjee ma na taniec odissi.

Jezioro Łabędzie było już adaptowane przez tancerzy klasycznego tańca indyjskiego. W tańcu mohiniyattam dokonano adaptacji według koncepcji Vijayalakshmi i według choreografii Bharati Shivaji, Vijayalakshmi i Santosh Nair. W tym spektaklu nie tylko pozostawiono oryginalne libretto, lecz także nie zmieniono muzyki Czajkowskiego. Nowe wcielenie temu utworowi nadano jedynie poprzez odmienne medium taneczne. Pick twierdzi, że transfer kulturowy „nie koncentruje się wyłącznie na tym, co lub w jaki sposób jest transferowane, ale co się z nowymi treściami w społeczeństwie przyjmującym dzieje. [...] w zakresie nowych treści

55. Ruth K. Abrahams, Uday Shankar: The Early Years, 1900-1938, „Dance Chronicle”, 2007, 30(3), s. 363-426 <http://www.jstor.org/stable/25598119> (01.09.2018).

56. Purkayastha, Indian Modern Dance..., s. 66.

57. Wywiad z Sharmilą Mukherjee przeprowadzony przez autorkę (Skype, 12.09.2018). 
wprawdzie nawiązuje do »obcego« oryginału, nie powiela go jednak całkowicie”58. Spektakl Hansika jako przykład transferu staje się bardziej interesujący z powodu wielopłaszczyznowych modyfikacji, na jakie zdecydowała się choreografka i reżyserka Sharmila Mukherjee. Zmiany można dostrzec zarówno w oryginalnej sztuce, jak i w samym tańcu. Celem choreografki była adaptacja tego klasycznego dzieła do indyjskiego kontekstu, czego rezultatem jest wyraźne oderwanie się od oryginału dzięki wprowadzeniu kilku widocznych elementów. Jak twierdzi Mukherjee: „Nadałam mu tak bardzo indyjski charakter, że ciężko to porównac’”59.

Pierwsza modyfikacja to muzyka, która - choć inspirowana oryginalną kompozycją Piotra Czajkowskiego - została stworzona w całkowicie nowej odsłonie przez Praveen D. Rao. Na samym początku słychać znaną melodię z Jeziora Eabędziego, którą choreografka postanowiła odtworzyć na indyjskich instrumentach, takich jak sitar, tabla, flet i skrzypce. W innych miejscach pojawia się też nierozłączny z tańcem odissi instrument perkusyjny - pakhawadź, do którego rytmicznie wybijanego rytmu tancerze wykonują taniec nritta w czystej formie. Zastosowano go w scenach takich, jak polowanie księcia czy wspólny taniec Odetty z przyjaciółkami, nadając sztuce wyrazisty styl muzyki klasycznego tańca indyjskiego.

Kolejny element, w którym choreografka wprowadziła modyfikację, to libretto. W Hansice Odetta i Odilla to dwie siostry rywalizujące w tańcu, a scena w sali balowej została zastąpiona sceną zaręczynową i posłużyła do zaprezentowania tradycji hinduskich. W wywiadzie choreografka opisuje scenę:

Przyjaciółki przychodzą z czerwonym welonem i girlandą kwiatową, które zakładają Odettcie, stopę malują jej altą (czerwona farba), rękę zdobią jej henną, na ciało rozprowadzają pastę z kurkumy, stroją ją i siebie, a także przygotowują salę weselną, czyli to, co robimy zawsze przed weselem ${ }^{60}$.

Jak dodaje Mukherjee, ta scena szczególnie spodobała się tancerkom indyjskiego tańca. Nic dziwnego, bo mogły doskonale utożsamić się nie tylko ze znanymi im tradycjami, ale też z bardzo popularnym motywem pojawiającym się $\mathrm{w}$ abhinaya w scenach Radhy i jej przyjaciólek pastuszek z poematu Gitagovinda. To samo dotyczy sceny Odetty bawiącej się nad jeziorem ze swoimi przyjaciółkami. Podobnie zbudowana jest też wspomniana wcześniej scena rywalizacji tanecznej sióstr, która nieuchronnie przywołuje obrazy z potyczek tanecznych z kultowych filmów bollywoodzkich, takich jak Raj Tilak z 1958 roku czy Amrapali z 1966 roku. Są to przykłady wysiłków choreografki, służących znalezieniu odpowiedników

58. Pick, Czym jest transfer kultury?..., s. 257.

59. Wywiad z Sharmilą Mukherjee... (12.09.2018).

60. Wywiad z Sharmilą Mukherjee... 12.09.2018). 
w kulturze indyjskiej w celu „dostosowania nowych treści do własnej kultury”61 $\mathrm{w}$ procesie przyswajania przedmiotu transferu.

Najłatwiejsze, jak twierdzi Mukherjee, w adaptacji okazało się przedstawienie psychologicznej strony sztuki. Z uwagi na rozbudowaną technikę abhinaya, gdzie emocje przekazywane są za pośrednictwem całego ciała i gestów angika, ale też wewnętrznych psychologicznych odczuć, satvika, Mukherjee miała możliwość podejścia do tej kwestii na wielu płaszczyznach, oferując widzom pełniejszy zakres emocjonalnych przeżyć. W Hansice przez abhinaya przedstawiane są emocje, takie jak śringara (miłość), raudra (złość), hasya (radość), adhbuta (zdziwienie) i karuna (smutek). Są one przekazywane przez tancerzy odissi nie tylko za pośrednictwem ruchu ciała, lecz także przez gesty dłoni i mimikę twarzy, co stanowi dopełnienie oryginału, w którym zgodnie z charakterystyką baletu dominuje fizyczny ruch ciała.

By usprawnić przekaz najistotniejszych treści sztuki, Mukherjee wprowadziła również w kilku kluczowych momentach narrację, na przykład podczas wspomnień Odetty opisującej księciu, dlaczego została zamieniona w łabędzia, czy w ostatniej scenie, w której Odille wyjaśnia, dlaczego książę nie znajdzie Odetty. Obok narracji kolejny nowy element to przekaz społeczny o środowisku naturalnym i wyniszczającym działaniu człowieka, który dopuszcza się do tak głębokiego zanieczyszczenia jeziora, że łabędzie w nich umierają. Mukherjee tłumaczy:

Problem zanieczyszczenia i degradacji środowiska naturalnego jest mi bardzo bliski, gdyż mieszkając w Bangalorze, mamy bezpośrednie do czynienia z wycinką drzew czy zanieczyszczeniem jezior i dlatego możliwość podnoszenia świadomości wśród społeczeństwa jest dla mnie bardzo ważna ${ }^{62}$.

W Hansice motyw ten został pokazany na samym końcu, kiedy Odetta zostaje na zawsze zamieniona w łabędzia, ale książę nie może jej odnaleźć i widzi, jak łabędzie odfruwają albo umierają. Stosując takie rozwiązanie, Mukherjee nadała sztuce nowego znaczenia, co umożliwia transfer kulturowy, ponieważ „wymiana kulturowa nie jest cyrkulacją obiektów i myśli takimi, jakie one są, lecz ich niekończącą się reinterpretacją, nowym przemyśleniem i tworzeniem nowych znaczeń" ${ }^{\prime 3}$.

Konieczne okazały się również zmiany w tańcu odissi. Można od razu spostrzec, że kostiumy uszyto nie z saree z Orissy, a z białych szyfonowych materiałów, do których doszyto też elementy przypominające skrzydła (Zdj. 2).

61. Pick, Czym jest transfer kultury?..., s. 257.

62. Wywiad z Sharmilą Mukherjee... 12.09.2018).

63. Michele Espagne, What is Cultural Transfer <https://eu.spb.ru/en/news/14094-what-is-cultural-transfer $>$ (10.05.2018). [Przeł. S.S.S.P.]. 


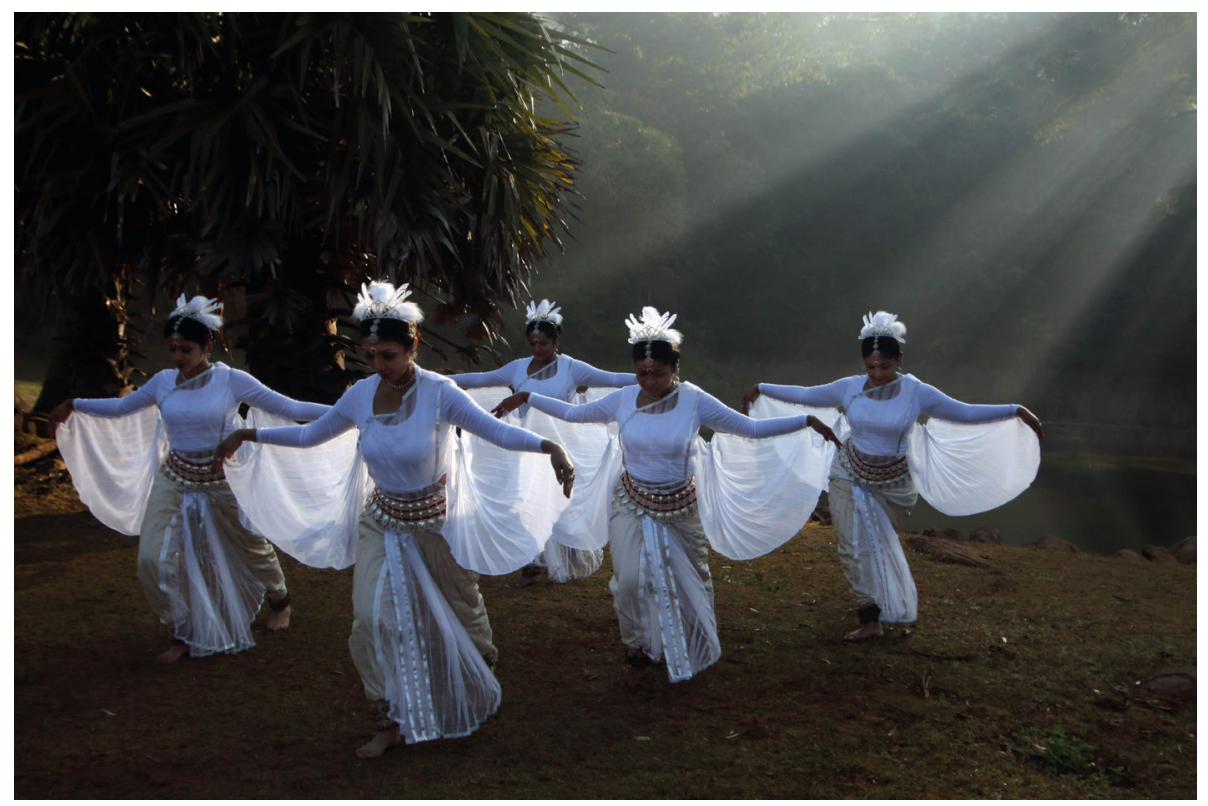

Zdj. 2. Zdjęcie promujące spektakl Hansika w choreografii Sharmili Mukherjee (zdjęcie: V.B. Suresh Babu)

Do włosów zamiast tradycyjnej korony z elementem nawiązującym do świątyni użyto korony $z$ białych piór. Tancerki odziano w bluzki z pełnymi rękawami, co nadało tańcowi indyjskiemu współczesny charakter. W żadnej z tych zmian Mukherjee nie widzi problemu, choć eksperymenty $\mathrm{z}$ tradycyjnym kostiumem często wzbudzają kontrowersje u krytyków i tradycjonalistów ${ }^{64}$.

Kolejne modyfikacje pojawiły się $\mathrm{w}$ samym tańcu. W pierwszej scenie $\mathrm{z}$ łabędziami tancerki tańczą bez ghungroo (dzwoneczki na nogach). Nie używa się też instrumentu pakhawadź w muzyce. Ruch łabędzi dryfujących na wodzie odtwarzany jest przy użyciu kroku na palcach, który nie jest stosowany w odissi. $\mathrm{W}$ innych miejscach użyto techniki pochodzącej z odissi: jednoczesnego poruszania się na palach i piętach, co sprawia wrażenie sunięcia czy dryfowania. Hansika to też gest dłoni obrazujący łabędzia. Warto dodać, że w samym tańcu odissi są ruchy, które pięknie oddają ruch łabędzia. Mukherjee wspomina, że „taniec łabędzi nie był trudny, jak Praveen dał mi muzykę, to już nie miałam trudności, mogłam znaleźć wiele ruchów łabędzia z tańca odissi, to po prostu

64. Zob. Nandini Sikand, Bodies and Borders: The odissi Costume Controversy, w: Dance Matters, red. Pallabi Chakravorty, Nilanjana Gupta, Routledge, Oxon, 2018, s. 49-65. 
wypłynęło samoistnie" 65 . Na przykładzie choreografii Mukherjee pokazuję działanie transferu kulturowego, którego rezultat jest „potwierdzeniem tego, co jest rdzenne, a zarazem, [...] prawdziwą integracją czegoś obcego”"66. Taniec odissi w znacznym stopniu odbiega od baletu, jeśli chodzi o kwestie relacji ciała względem grawitacji. Balet przeciwstawia się grawitacji, idąc ku górze w skokach i w podniesieniach, a odissi, ze swoimi mocnymi tąpnięciami stóp, rytmu i wibracji uzyskiwanych dzięki kontaktowi bosej stopu z podłożem, idzie ku dołowi. W tej kwestii, jak zauważono po pokazie, „choć tancerki tańczyły głównie w stylu odissi, było wiele momentów odejścia od jego idiomu, jak: wejście na scenę przez boczne przesuwanie [na palcach stóp - S.S.S.P.], które dobrze spełniło funkcję

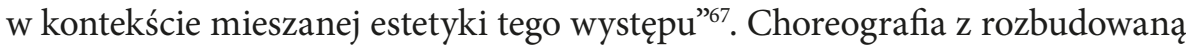
kompozycją figur i idealną synchronizacją to punkt odniesienia do baletu, jaki miała na uwadze Mukherjee, tworząc Hansikę. Dla niej był to jeden z priorytetów. Jak opisuje Sammitha Sreevathsa: „Ogólnie estetyka występu jest całkowicie podyktowana wizualnością i jakością, która przypomina tradycję baletu”68. Ten opis sugeruje, że Hansika wyraźnie odbiega od tradycji solowych występów w odissi, ale jednocześnie obecność innej tradycji poszerza zakres prezentacji scenicznej tańca odissi.

Jako całość Hansika przybiera format spektaklu taneczno-teatralnego, osadzonego w historii uniwersalnej z 25 tancerzami na scenie, dzięki czemu może trafić do większego grona odbiorców. Temu celowi służy również zastosowanie narracji w języku angielskim. Rezultatem modyfikacji, na które zdecydowała się choreografka i reżyserka w adaptacji dzieła, stał się spektakl, który jest zrozumiały dla widzów „w domu”, czyli dla tancerzy indyjskich, ale też dla osób niezwiązanych z tańcem indyjskim. Przy wpływach zachodniej popularnej i rozrywkowej muzyki oraz tańca, trudność, z jaką borykają się tancerze tańców klasycznych, to zainteresowanie młodego pokolenia kulturą klasyczną. W wyniku transferu kulturowego Mukherjee stworzyła jedną z takich możliwości. Ponadto spektakl ma też przemawiać do widzów „spoza domu”, czyli spoza kultury indyjskiej. Skoro transfer nie jest procesem jednostronnym, a jak zaznacza Pick: „jest procesem wzajemnym, aktorzy istnieją po obu stronach "69 lub podróżują, to można stwierdzić, że Hansika, jako spektakl silnie osadzony w kulturze indyjskiej, ma możliwość bycia przedmiotem transferu kulturowego także w drugą stronę, gdy zostanie zaprezentowany w Europie. Jak opisuje Mukherjee: „Hansika ma międzynarodo-

65. Wywiad z Sharmilą Mukherjee... (12.09.2018).

66. Middell, European History and Cultural Transfer..., s.26.

67. Sammitha Sreevathsa, No Gains in Translation, „The Hindu” <https://www.thehindu.com/ entertainment/dance/no-gains-in-translation/article23441506.ece> (04.06.2018).

68. Sreevathsa, No Gains in Translation...

69. Pick, Czym jest transfer kultury?..., s. 258. 
wy temat, ale indyjskie poczucie estetyki "70. $\mathrm{Z}$ uwagi na zainteresowanie kulturą Indii w Europie, przy jednoczesnym wzroście populacji pochodzenia indyjskiego, spektakle tego rodzaju stwarzają szanse na pogłębienie praktyk tańców indyjskich oraz na zastosowanie indyjskich metod performatywnych na gruncie europejskim.

Omówione przeze mnie zjawiska potwierdzają adekwatność zastosowania w tej analizie metody transferu kulturowego, gdyż - jak zauważa Jabłkowska - przy innych metodach, jak na przykład porównanie, mamy do czynienia ze „wzajemną recepcją i zestawieniem,” a w tym przypadku ma miejsce „dynamiczny proces” i „długotrwała osmoza" ${ }^{1}$. Podobnie metoda kontaktu, skupiająca się na konkretnych przykładach spotkania kultur, nie oddaje w pełni charakteru omówionych zjawisk. Metodą, która mogłaby nadać nową perspektywę analizie wzajemnych wpływów w tańcu odissi, i tym samym poszerzyłaby analizę dokonaną w obecnej pracy, wydaje się mobilność kulturowa zaproponowana przez Stephena Greenblatta ${ }^{72}$. Jednak na tym etapie zastosowanie metody transferu kulturowego w analizie tańca odissi, który zawsze pozostawał otwarty na wpływy zewnętrzne, pozwoliło na uwypuklenie pewnych kluczowych zjawisk w rozwoju tego tańca. Przyswojenie zawsze było istotne w podejściu do nowych treści, jak tłumaczy Dinnanath Pathy: „,[C]elem jest usprawnienie procesu napływu kulturalnego tak, by nadawał się do naszej własnej interpretacji"73. Przytoczone tu przykłady transferu kulturowego potwierdzają słowa Pathy i pokazują, jak zachodnie techniki, idee, motywy i metody zostały zaadaptowane do metodologii nauczania i w samym tańcu odissi, za każdym razem dając praktyczny rezultat oraz uzupełniając „potrzeby grupy przyjmującej”74. Współpraca Surupy Sen oraz Bijayini Satpathy z różnymi artystami z Indii i z zagranicy wykształtowała filozofię Nrityagram, którą można by określić jako „globalny indyjski styl życia pozwalający na harmonijną koegzystencję oczywistych paradoksów, jak tradycja i współczesność; »rdzenny« i »zagraniczny« do tego stopnia, że kategorie te stają się powikłane" 75 . W przypadku Nrityagram struktura, organizacja, sposób wykonywania i doświadczenia, wszystko jest kombinacją lokalnych i globalnych filozofii oraz metodologii. Jak podkreśla Middell, nie chodzi tu o wpływ jednej kultury na drugą, lecz o „integrację elementów z kultury obcej z kulturą zdefiniowaną

70. Wywiad z Sharmilą Mukherjee... 12.09.2018).

71. Jabłkowska, Transfer kulturowy czy po prostu kontakty?, s. 32.

72. Stephen Greenblatt, Cultural Mobility: A Manifesto, Cambridge University Press, Cambridge, 2010.

73. Dinanath Pathy, Re-thinking odissi, Harman Publishing House, New Delhi, 2007, s. 292 [przeł. S.S.S.P.].

74. Pick, Czym jest transfer kultury?..., s. 258.

75. Brosius, India's Middle Class..., s. 69. 
jako rodzimą"76. Poza przyswajaniem treści obcych do swoich własnych, efektem dodatkowym okazuje się też otwarcie się kultury przyjmującej dla kultur obcych, i tym samym stworzenie warunków do swego rodzaju cyklu wymiany kulturowej. Można to było zaobserwować przy wędrówce, przenoszeniu, przeobrażaniu i wymiany praktyk somatycznych i holistycznych ze Wschodu na Zachód i z powrotem na Wschód, czy też przy współpracy Uday Shankar z Anną Pavlovą nad tematami hinduskimi w balecie europejskim, a później w adaptacji dzieła rosyjskiego baletu do tańca odissi przy Hansice. Transfer kulturowy w takim wydaniu prowadzi zatem do uruchomienia swojego rodzaju nieustannie zapętlającego się obiegu przedmiotów, przy stale zmieniającej się koniunkturze i coraz bardziej mobilnych uczestnikach transferu kulturowego.

76. Middell, European History and Cultural Transfer..., s.26. 
